Ann. Zootech., 1980, 29, no h. s., 275-284.

\title{
The influence of energy and protein level on the carcase and lean quality in young bulls
}

\author{
K. KOUSGAARD
}

The Danish Meat Research Institute, Roskilde, Denmark.

\begin{abstract}
On the initiative of the National Institute of Animal Science a number of experiments have been carried out in recent years in Denmark to investigate the effect of energy and protein level on the production characteristics of young bulls slaughtered at different liveweights.

These experiments have shown that the best carcase and lean quality is obtained with intensive feeding, but that it is necessary to take into account the weight at which the bulls are to be slaughtered, and whether early or late maturing breeds are being used.

Furthermore, the experiments showed that the protein level can be varied within quite wide limits without any effect on carcase and lean quality being observed.
\end{abstract}

\section{Résumé}

Influence du niveau des apports énergétiques et azotés sur la qualité des carcasses et des viandes de taurillons

A l'instigation de l'Institut National des Sciences Animales plusieurs expériences ont été conduites au Danemark ces dernières années pour étudier l'influence du niveau des apports énergétiques et azotés sur les caractéristiques de la production de taurillons abattus à différents poids vifs.

Ces expériences ont montré que les carcasses et viandes de meilleures qualités ont été obtenues avec un niveau d'alimentation intensif, mais il fallait cependant tenir compte aussi du poids d'abattage et de la «précocité » des races utilisées.

En outre, ces expériences ont montré que le niveau azoté pouvait varier dans des limites assez larges, sans aucun effet notable sur les qualités de carcasse et des viandes. 


\section{Introduction}

In Denmark nearly all bull calves are intensively fed. They are slaughtered now at a liveweight of about $400 \mathrm{~kg}$, as against $230-250 \mathrm{~kg}$ liveweight previously.

The carcases are almost exclusively sold on the Italian market, which demands a good conformation, a rather thin layer of tallow, and meat which is light in colour. To furfil these requirements it is necessary to know how the energy and protein level influences carcase and lean quality.

Thus, a number of experiments have been carried out in recent years to establish the optimum feeding method, which also takes into account the steadily increasing requirements for carcase and meat quality.

\section{1. - The influence of energy level on carcase and lean quality}

\section{Experiment 1.}

An extremely detailed experiment, known as RefsGaARD's experiment, was carried out in Denmark in the period 1969 to 1973 . The aim of this experiment was to investigate the effect of different slaughter weight and energy levels on young bulls (REFSGAARD ANDERSEN, 1974 ; KOUSGAARD, 1974 ; LiS BUCHTER, 1975). A total of 168 young bulls of the Danish Red breed were divided into 7 different slaughter weights $(180,240,300,360,420,480$, and $540 \mathrm{~kg})$ and 4 different energy levels $(100,85,70$ and 55 per cent). The results for carcase quality, which are probably well known, are shown in Table 1.

The following can be seen from Table 1 :

a. The dressing percentage increases with increasing slaughter weight and increasing energy level. This was not, however, true for the lowest energy level.

b. Conformation (the shape of the carcase) was clearly poorer with a low energy level than with a moderate or high energy level. This is related to the fact that the animals' degree of fatness falls with decreasing energy level.

c. The percentage of meat in the cheaper cuts, the flank, flatribs, brisket and shin, is more or less the same, irrespective of the slaughter weight or energy level. The percentage of tallow increases markedly with increasing slaughter weight for ad libitum feeding, while the percentage of bone falls slightly.

With intensive feeding the lean content of the shoulder, neck and forerib is about 20 per cent for all slaughter weights, while with low energy level feeding an increase is seen with the highest slaughter weight. This increase can perhaps be explained by the fact that the bulls have reached an age of 15 to 16 months and are beginning to develop a bull neck.

The percentage of meat in the pistol cut decreases with increasing slaughter weight for all energy levels. With respect to tallow and bones a greater increase and a greater decrease, respectively, is seen with the high as compared to the low energy level. The weight of the pistol cut falls with increasing slaughter weight from about 49 - 50 per cent to about $44-45$ per cent, and this decrease is almost exclusively due to a drop in lean content. 


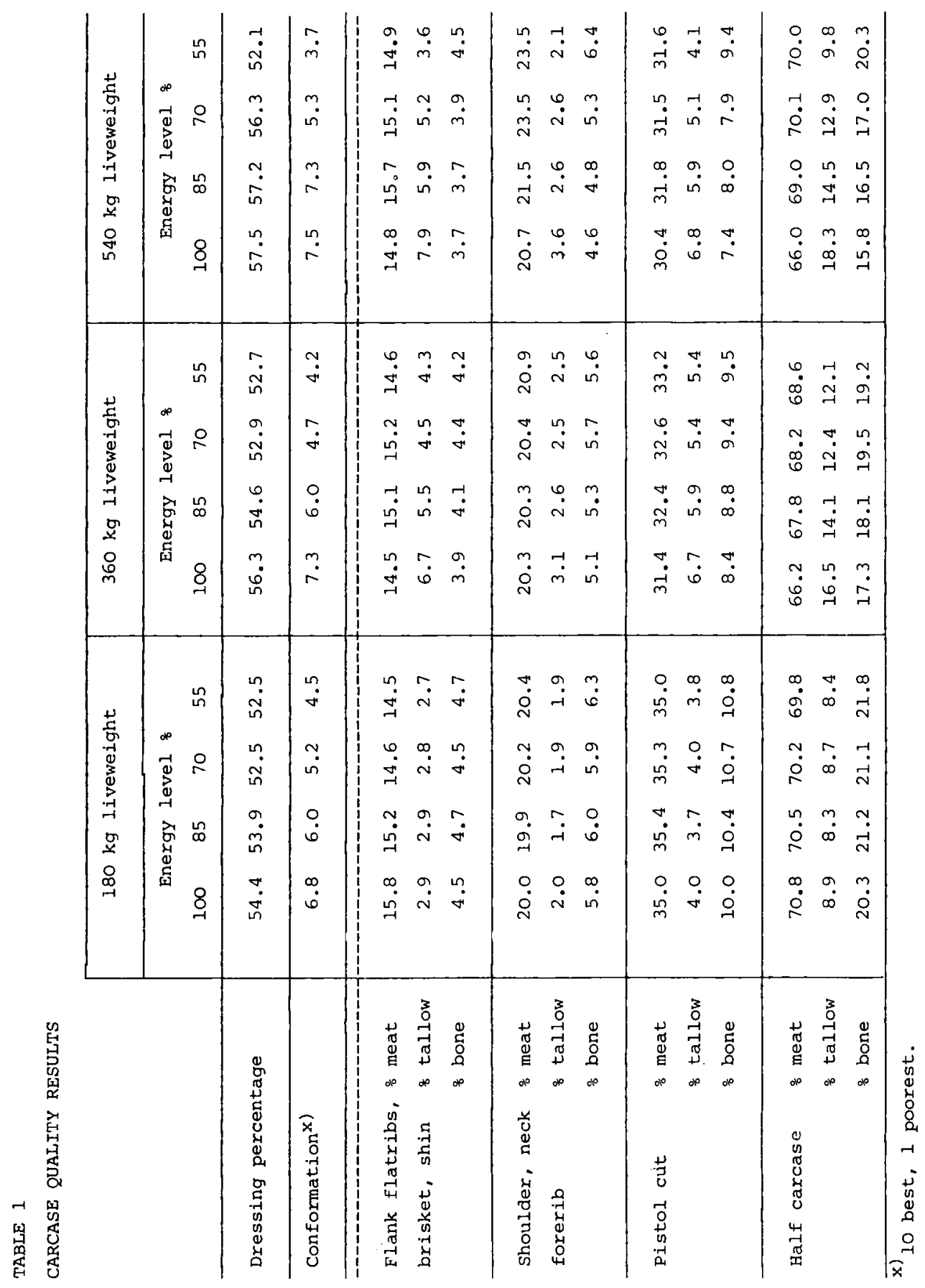




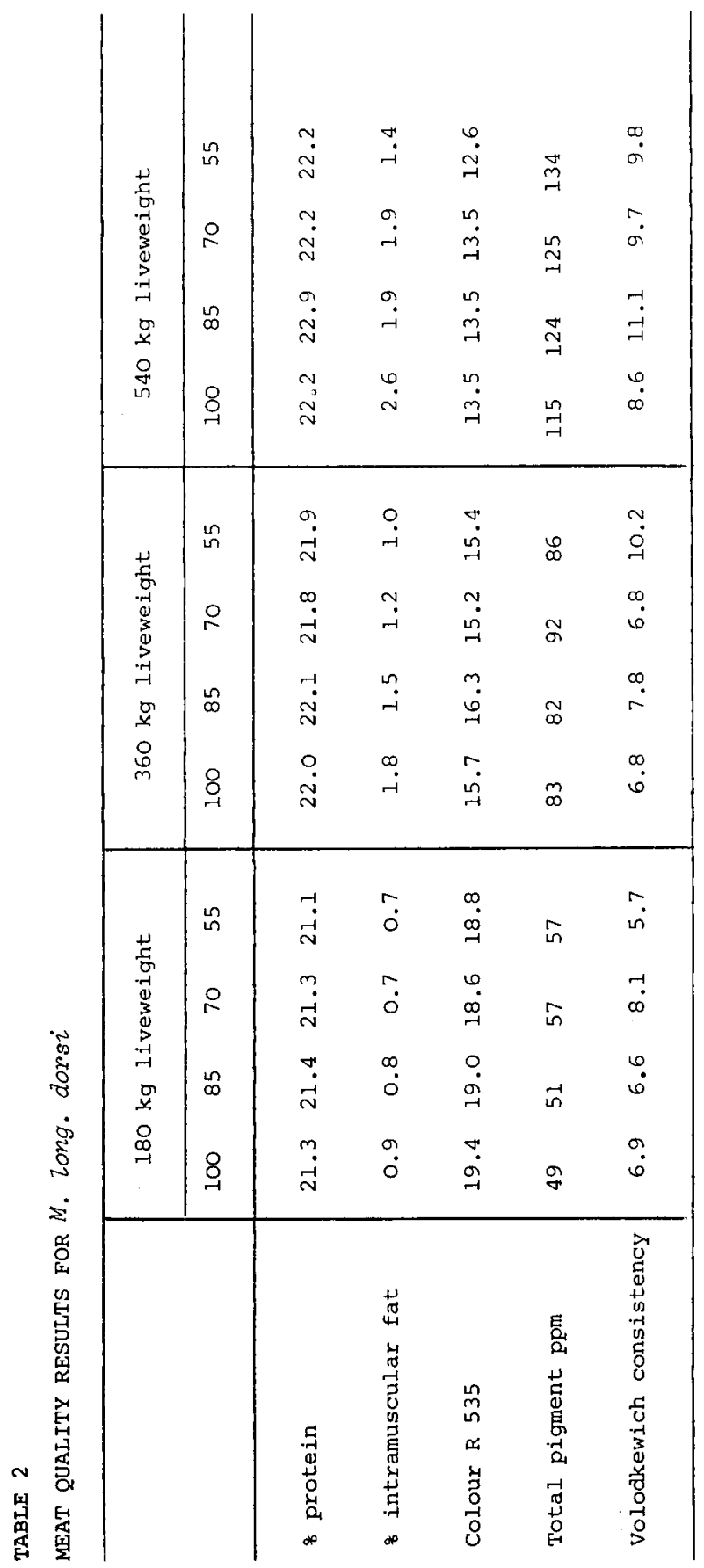


The lean quality investigations consisted of an estimation of the per cent protein, per cent intramuscular fat, reflectance value ( $R$ 535), total pigment, consistency value and the $\mathrm{pH}$ in the longissimus dorsi, triceps brachii, semitendinosus and semimembranosus muscles. The results for the longissimus dorsi muscle are shown in Table 2 . The samples from animals with a liveweight of $180 \mathrm{~kg}$ were matured at $4^{\circ} \mathrm{C}$ to 7 days after slaughter, while the samples from animals slaughtered at 360 and $540 \mathrm{~kg}$ liveweight were matured to 10 days after slaughter.

The results were as follows :

a. The protein content of the meat increases slightly with increasing slaughter weight, but is almost unaffected by energy level.

b. The fat content increases both with increasing slaughter weight and increasing energy level, but energy level only becomes really important at the highest slaughter weight.

c. Lean colour becomes darker with increasing slaughter weight and decreasing energy level, although the latter's effect is somewhat limited. Changes in pigment content more or less follow the changes in reflectance value.

d. The consistency value is especially affected by increasing slaughter weight, and to a much lesser extent, by decreasing energy level. The consistency value, however, does not register the changes in connective tissue, which occur with increasing age and weight to any great extent, so a taste panel is more effective in registering increasing toughness with increasing slaughter weight, a fact that was shown by VESTERGAARD (1974) on a small number of animals.

\section{Experiment II}

A crossbreeding experiment with young bulls, which is not yet finished, is being carried out in collaboration with the National Institute of Animal Science (LibORIUSSEN et al., 1978). In this experiment three different slaughter weights and three different energy levels (ad libitum, 85 per cent and 70 per cent) are being investigated. The results, which have not yet been published are shown in Table 3.

The differences found were highly significant and were those expected from previous experiments in that both increasing slaughter weight and increasing energy level resulted in a higher slaughter yield, a better conformation with a higher degree of tallow covering, and a higher percentage of tallow. Both lean and bone content fell with increasing slaughter weight and increasing energy level.

As the experiment involved crossbreeding, it is also interesting to see how there is a significant interaction between energy level and sire breed.

The lean quality investigations are not yet finished, but a preliminary survey which includes the results from 278 animals, shows that the tenderness of the meat deteriorates significantly, both with increasing slaughter weight and decreasing energy level.

\section{Experiment III}

In another unfinished experiment with the title "The influence of different slaughter weights and energy levels on growth rate, feed conversion, and carcase and lean quality of young bulls and steers (Danish Friesian)", the aim is to 


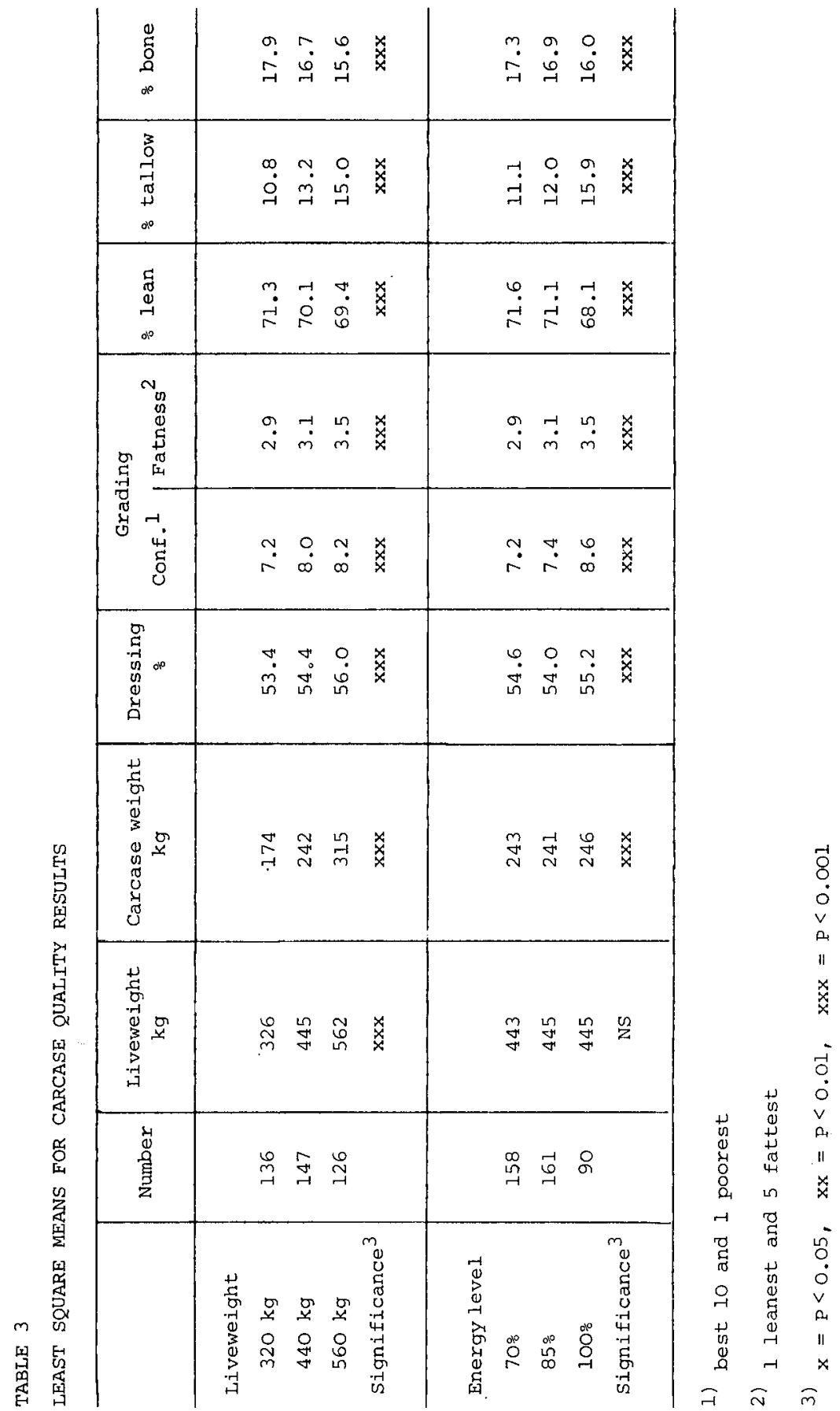




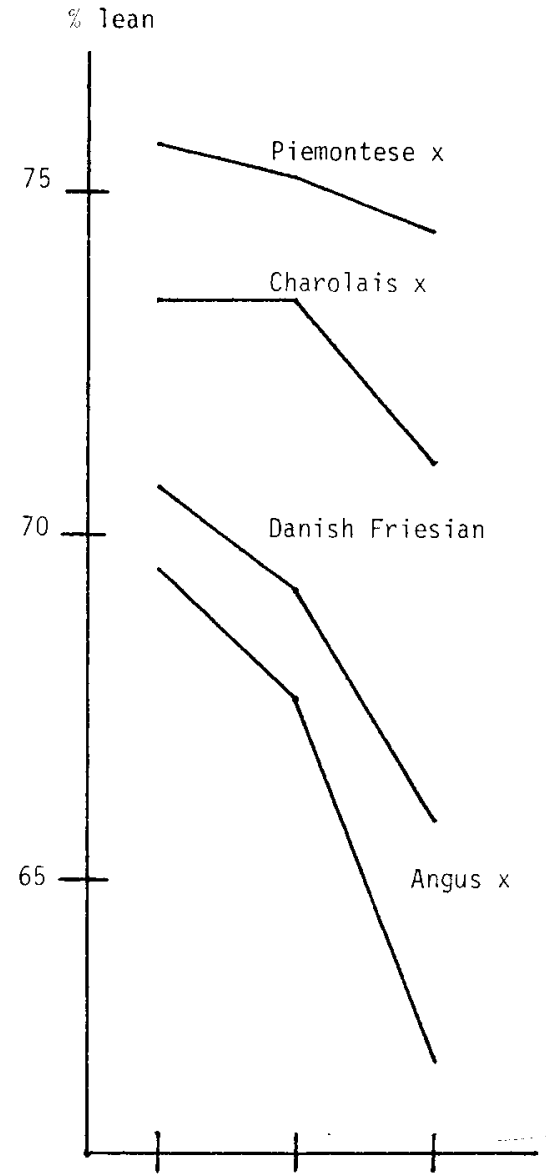

$70 \%$

ad. 1 ib.

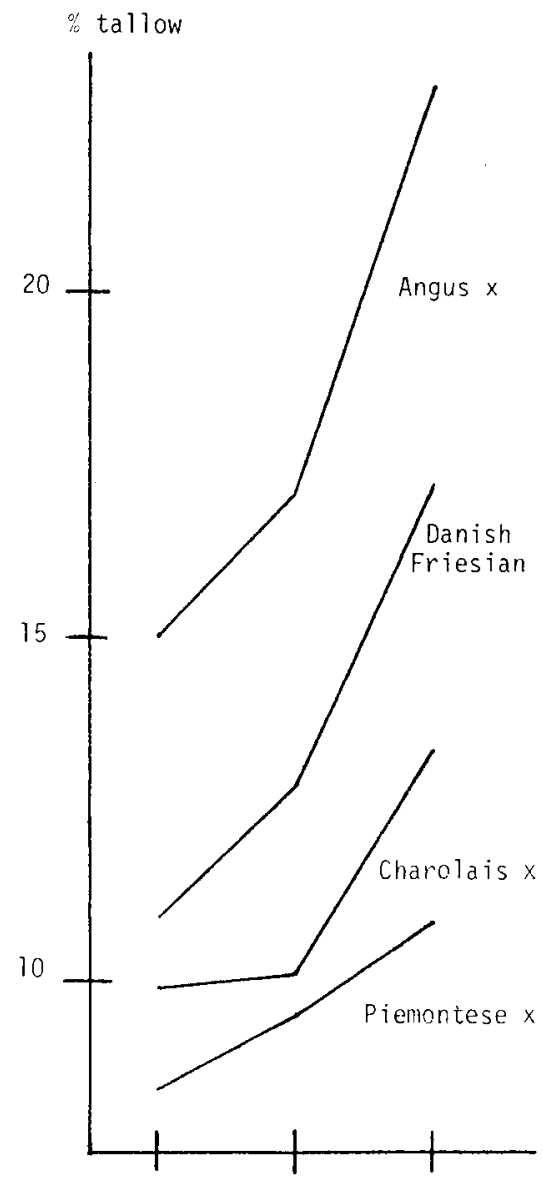

70

85

ad. 1 ib.

Fig. 1. - Interaction between sirebreed and feeding energy.

investigate slaughter and lean quality with ad. libitum, 85 per cent and 70 per cent feeding, as well as to see what happens when animals fed at the 70 per cent level are fed ad libitum for the last $125 \mathrm{~kg}$ before slaughter. The young bulls and steers were slaughtered at a liveweight of 425,550 , and $675 \mathrm{~kg}$, and for young bulls only, also at $800 \mathrm{~kg}$. The preliminary results are shown in Table 4 .

The following can be seen from Table 4 :

a. The greatest difference between young bulls and steers is found in lean and tallow content.

b. With increasing slaughter weight a similar development to that found in previous experiments was observed.

c. The effect of increasing energy level is also that expected, but it is interesting to see that ad libitum feeding the last $125 \mathrm{~kg}$ before slaughter gives almost the same resuits as feeding with 85 per cent energy level for the whole of the experimental period. 


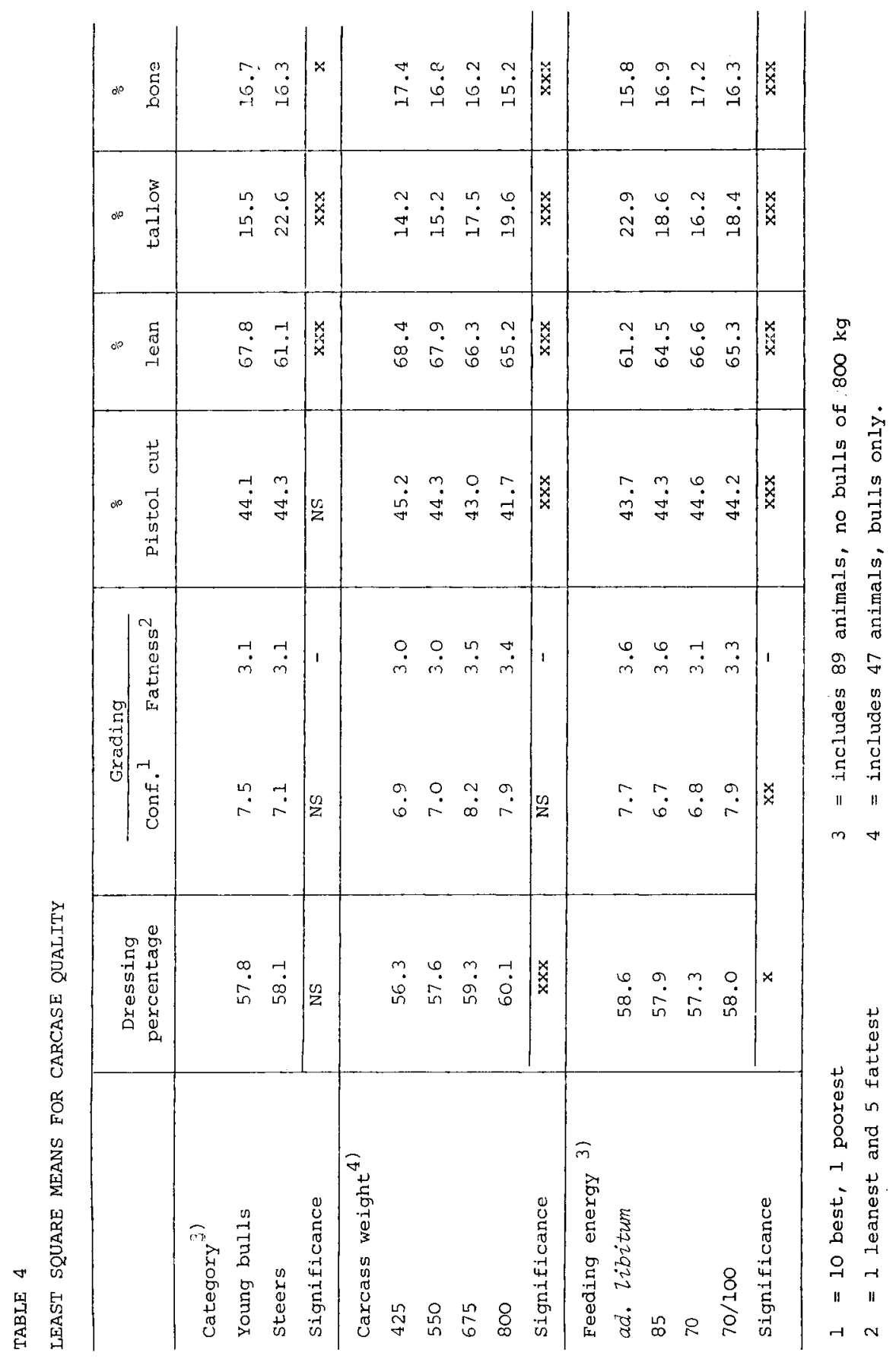


d. It should be noted that a significant interaction between category of animal and slaughter weight was found for per cent tallow and per cent bone, as well as between slaughter weight and energy level for per cent lean and per cent tallow.

With respect to lean quality, steers have a lower consistency value and a higher fat content in the lean compared to young bulls. Moreover, the lean becomes darker and the intramuscular fat content increases with increasing slaughter weight. Ad libitum feeding for the last $125 \mathrm{~kg}$ before slaughter seems to improve lean quality.

\section{2. - The influence of protein level on carcase and lean quality}

A series of experiments were carried out in Denmark in the period 1966 to 1971 to bring the protein norms used at that time up to date (ANDERSEN et al., 1973 ; SORENSEN and KOUSGAARD, 1976). The experimental material consisted of 156 young bulls of the Danish Red and Danish Friesian breeds, which weighed $160 \mathrm{~kg}$ at the start of the experiment and $500 \mathrm{~kg}$ at slaughter.

The experiments showed that a ration of $110 \mathrm{~g}$ of digestible crude protein at the beginning of the experimental period and $70 \mathrm{~g}$ at the end was sufficient to ensure an acceptable daily weight gain and carcase and lean quality. The experiments showed, moreover, that the protein content of the feed could vary from $75 \mathrm{~g}$ to $135 \mathrm{~g}$ per unit, without any effect on carcase and meat quality.

The protein norms, which are recommended, are as follows :

\begin{tabular}{rccc}
\multicolumn{4}{c}{ Protein standards for fattening calves and young bulls } \\
\hline \multicolumn{3}{c}{ W digestible crude protein } \\
\cline { 2 - 4 } Weight, $\mathrm{kg}$ & per f.u. & per day & f.u. per day \\
\hline-100 & 115 & 250 & 1.6 \\
$100-150$ & 135 & 400 & 3.0 \\
$150-200$ & 115 & 440 & 3.8 \\
$200-250$ & 100 & 500 & 5.0 \\
$250-300$ & 90 & 500 & 5.6 \\
$300-350$ & 85 & 550 & 6.5 \\
$350-400$ & 80 & 550 & 7.0 \\
$400-450$ & 75 & 550 & 7.1 \\
$450-500$ & 75 & 550 & 7.4 \\
& & & \\
\hline
\end{tabular}

In the previously mentioned, unfinished, crossbreeding experiment two different protein levels were used for the animals on restricted feeding, i.e. 114 and $138 \mathrm{~g}$ digestible crude protein per feed unit. The results showed a slightly lower feed conversion, better daily gain, better conformation and a slightly lower meat and tallow content in the animals with the highest protein level. It is not possible 
to give any direct explanation for this deviation from previous results, but some things point to the fact that protein quality is important, as the effect was only seen in one of the experimental years.

\section{Conclusions}

Intensive feeding is necessary for young bulls if the best possible carcase and lean quality is to be ensured.

When slaughtering at a high liveweight, it is possible to feed restrictively in the first part of the fattening period, if the animals are fed ad libitum in the last part of the fattening period.

With respect to energy level, it should be noted that the optimum slaughter weight is different for the different breeds and breed combinations, and that there is an interaction between breed and energy level.

The protein level can be varied within quite wide limits without any effect on carcase and lean quality.

Steadily increasing requirements for carcase and meat quality make it necessary that the optimum feeding method be used, and this method will depend on both slaughter weight and breed.

\section{References}

ANDERSEN H.R., 1974. Slagtevagtens og foderstyrkers indflydelse pa vakst, foderudnyttelse og slagtekvalitet hos RDM-ungtyre. (The influence of slaughter weight and feeding level on the growth, feed conversion, carcass composition and conformation in RDM-bulls). Thesis, Licentiatafhandling, K.V.L., Kobenhavn, 154 pp.

ANDERSEN H.R., 1975. Slagtevagtens og foderstyrkers indflydelse pa vakst, foderudnyttelse og slagtekvalitet hos ungtyre. (The influence of slaughter weight and feeding level on the growth, feed conversion, carcass composition and conformation in bulls). (In Danish with English summary and subtitles). 430. Beretn. Statens Husdyrbrugsforsog, Kobenhavn, 124 pp.

ANDERSEN H.R., 1975. The influence of slaughter weight and level of feeding on growth rate, feed conversion and carcass composition of bulls. Livest. Prod. Sci., 2, 341-356.

ANDERSEN H.R., 1977. Effect of energy level on growth and efficiency. Contribution to the EEC seminar on beef production held at Ghent, October 11-13.

Andersen P.E., Brolund Larsen J., Sorensen M., OstergaArt V., 1973. Optimal proteinforsyning til Kvag. II. meddelelse fra Landok. Forsogslab., 34 pp.

BUCHTER L., 1975. Slagtevagtens og foderstyrkens betydning for produktions-, slagtekvalitets- og kodkvalitetsegenskaber hos fededyr. Arbejde nr. 01.383 - rapport II (1. juli Kreaturer-Kodkvalitet). Slagteriernes Forskningsinstiutut, Roskilde.

GeaY Y., Robelin J., 1979. Variation of mean production capacity in cattle due to genotype and level of feeding : genotype - nutrition interaction. Livest. Prod. Sci., 6, $263-276$.

KousGaARD K., 1974. Slagtevagtens og foderstyrkers betydning for produktions- og slagtekvalitetsegenskaber hos fededyr. Arbejde $n r .01 .383$ - rapport I (26 november, KREATURER-KodKVALITET). Slagteriernes Forskningsinstitut, Roskilde.

Liboriussen T., Refsgaard Anderšen H., Bech Andersen B., Kousgaard K., Lis Buch. TER, 1978. Krydsnings-og produktionsforsog med kod og kombinationsracer, serie II. I. Forsogsplan. Kort meddelelse nr. 251. Statens Husdyrbrugsforsog.

Sorensen N. Marinus, Kousgaard K., 1976. Proteinmangdens indflydelse pa tilvakst, slagtekvalitet og kodkvalitet hos fedekalve og ungtyre. In Danish (with English summary and subtitle). 437 beretning fra Statens Husdyrbrugsforsog.

VESTERGAARD T., 1974. Oksekodets morhed $i$ relation til slagtedyrenes vagt, kon og energiforsyning. Licentiatafhandling, K.V.L., Kobenhavn, 97 pp. 